\title{
Names in Multilingual-Multicultural Malaysia
}

\author{
Karen Kow Yip Cheng \\ University of Malaya, Malaysia
}

Malaysia is a multilingual-multicultural country. A study of personal and family names in Malaysia is not only interesting but also profound as this country is composed of three major ethnic groups: Malays, Chinese, and Indians. A name is one of the things that give individuals their own special identity, while also helping others identify the person. The focus of this paper is on ethnicity and names with special reference to Self Identity, Ethnic Identity, and Nation Identity. Factors affecting the above include race, religion, culture, language, dialect, and nationality. Issues that arise from such a study are of great importance not only to the individual but also to the individual as a member of a family and of a particular ethnic group, and at the macro level, as a member of a nation.

\section{Is Identity a Choice?}

On top of giving each individual a special identity, a name also helps us distinguish one person from another. Furthermore, names can affect the psychological development of an individual. It is believed that names are magical and can have a 'selffulfilling' effect. Hence a good name leads to a good life and vice versa. Our name can determine how others behave towards us, perhaps a regal name invites regal treatment and the opposite may be true.

Names are multifunctional in that they not only differentiate one person from another but at the national level allow individuals to be enumerated and accounted for in such matters as creating polling lists and school registration lists. Thus, historically, names were a need imposed by those organizing their nations. Such needs have been felt at different times in different places; for example, in the Philippines surnames were first introduced in 1850 and then mandated in 1930, while in Switzerland they were mandated in 1863 , and in Thailand in 1875 . This shows that historically surnames were not just a personal choice, but a need imposed by those organizing political units.

\section{How important is a name?}

In June of 2005, the Star, a daily tabloid in Malaysia, reported on how a new mother's baby went missing hours after her delivery. The tabloid reported that 
although the father, Mohamad, felt he could rely on the police to find his missing baby, he also sought help from a bomoh or a medium. Unfortunately, the report continued, it was difficult for the bomoh to locate the baby because she needed the baby's name and Mohamad and his wife Noryati had not yet given her a name. A name is required for a bomoh to cure or to cast a spell.

Among the traditional Chinese, newborns go through a ceremony where they are introduced to their ancestors at the ancestral tablet. The Chinese in Malaysia also hold a Full Moon ceremony, when the baby is one month old. On this occasion, the parents announce to all kin and friends the happy and auspicious occasion of the baby being a month old. Today, parents in Malaysia distribute a box filled with foods that are symbolic. This box contains, among other things, red eggs that symbolize a new life and ang ku kuih, which are red round cakes, auspiciously named 'red turtle' as a symbol of longevity. In this ceremony, the newborn is introduced to members of the family and close friends, similar to the Western tradition of baptism, in which babies are brought before the members of a church and accepted into the faith and the community.

\section{Chinese names}

The Chinese can trace their ancestry and family via their names. Below are the proper names assigned to two different generations in a Chinese family:

$\begin{array}{llll}\begin{array}{l}\text { First Generation } \\ \text { Surname }\end{array} & \begin{array}{l}\text { Generation } \\ \text { name }\end{array} & \begin{array}{l}\text { Individual } \\ \text { name }\end{array} & \text { Gender } \\ \text { Kow } & \text { Koon } & \text { Fah } & \\ \text { Kow } & \text { Koon } & \text { Soon } & \text { Cheng } \\ \text { Kow } & \text { Yip } & & \mathrm{M} \\ \text { Second Generation } & & \text { Individual } & \\ \text { Surname } & \text { Generation } & \text { name } & \text { Gender } \\ \text { Kow } & \text { Kame } & \text { Fui } & \\ \text { Kow } & \text { Kean } & \text { Fung } & \mathrm{M} \\ \text { Kow } & \text { Kean } & \text { Fatt } & \mathrm{M} \\ \text { Kow } & \text { Kean } & \text { Yik } & \mathrm{M} \\ \text { Kow } & \text { Pik } & \text { Yoke } & \mathrm{M} \\ & & & \mathrm{F}\end{array}$

Tracing the Kow family one sees that ancestry is very important to the Chinese. Further family ties are also important and hence the need for a generation name. Emma Woo Louie (2006: 2I5) points out that:

While the Chinese also repeat the same theme word in the names of siblings, it is unlikely to appear in the names of family members belonging to different generations. The whole purpose for having names to indicate kinship is to be able to distinguish members of one generation from previous and succeeding ones ... In traditional China, knowing the generation name enabled proper behavior and respect toward all persons older than oneself. 
The girls in the family carry a different generation name and in some families there is no requirement for a generation name for girls, which reflects the strong patriarchal system practiced among the Chinese. There is no stipulated need for a generation name among girls as they will no longer carry the family surname once they are married. A mother's children will carry her husband's surname and not hers.

It can be seen then that the Chinese name system is one that stresses the importance of maintaining the ancestor's name. It is quite simply a way of maintaining the patriarchal system thus ensuring the male lineage in every family. This explains why the Chinese treasure sons because sons are needed to carry on the ancestry and lineage. Reid (2006) sees the patriarchal system as one that is mercantile, that is, a business relationship where the business partners with the same surnames can trust each other, even through many generations. Further it propagates capitalism with the accumulation of property via the eldest male member of the family continuing over generations. The naming system is viewed as a win-win situation because in addition to aiding the family it facilitates the work of the governing body whose role is to organize the country.

The strong patriarchal system that is maintained via the name system in China up until recently is clearly seen in the recognition of only male heirs by the Confucius clan. It was only in 2006 that this stand changed and China recognized Confucius women kin for the first time. In traditional Confucian thinking, women were accorded little status and were expected to serve their men folk. Today, the Confucius clan recognizes that men and women are equal even if a woman has to leave the family when she gets married to live with her husband. (Star, 27 September 2006).

The naming system among the Chinese is functional and this is seen in the fact that surnames determine who one can marry and who one cannot marry. Long before the days of DNA testing, the Chinese already had a simple system in place to prevent the occurrence of incestuous relationships. This was done via surnames, for example, a Lim would not marry a Lim and if they did then the family tree would be consulted to avoid problems that would result from inbreeding.

\section{Malay names}

In the naming system of the Malays there are no surnames; rather the ninety-nine names of the prophet Muhammad are commonly used. In the case of Malays in Malaysia, it is not so much lineage but the immediate father's identity that is of importance. This is in line with the Quran in Hadis Riwayat Abu Daud where it is stated that in the end days one shall be called by one's name and his father's name and therefore a Muslim must be sure that he makes a good name for himself. 'Kamu sekalian pada hari kiamat akan dipanggil dengan nama kamu dan nama bapa kamu, maka hendaklah kamu memperelokkan nama kamu' (Hadis riwayat Abu Daud).

Let us examine an example; Mohammad Bin Seman means that the individual's name is Mohammad and his father is Seman. Gender is also highlighted with males designated as Bin and females as Binti. On marriage, a female takes the husband's name, for example:

Maiden name: Suraiya Binti Kamardin

Husband's name: Ali Bin Rosli

Married name: Puan Suraiya Ali (Mrs Suraiya Ali) 
In tracing a typical Malay family tree one finds that ancestry is not the focus. Rather the immediate family and generation is what counts.

The Muslim religion plays a very important role in the Malay name system. A good name is like a prayer and the hope of the parents for their child's future. Hence a good name mirrors the desire of parents that their child will grow up to be a blessing to the family and society. The important role played by religion is also seen in the fact that after a Muslim devotee fulfills his pilgrimage to Mecca, the holy land of the Muslims he carries Haji in his name. This is recognition of the fact that he has fulfilled the Haj. The female counterpart would carry Hajjab in her name.

\section{Indian names}

Until recently the Indian name system did not have surnames, but this is changing. Unique to Indian names in Malaysia is the addition of $\mathrm{d} / \mathrm{o}$ or s/o, for example, Geetha d/o (daughter of) Govindaraju and Mohan s/o (son of) Raju. Traditionally names among the Indians have symbolic meanings and are associated with caste, ancestor, place or gods. Today, modern Indians have creatively developed non-traditional names by, for example, combining the names of the parents.

Among Indians who are Hindus, names are chosen based on date and time of birth or what is known as the Nakshatra of the baby. It is believed that each constellation has an equivalent Sanskrit letter, for example, Ra, Ri, So, etc. Hence a baby is not named by the parents but rather by a priest who is given the date and time of the baby's birth. The priest then uses numerology to come up with a name for the baby.

\section{Factors that can determine one's identity}

In a small survey taken among colleagues and students at the university representing all three ethnic groups, fifteen respondents were asked to list the top three factors which they thought affected their identity. Language was listed by ten of the fifteen respondents as most important. Next came culture or nationality, and third came dialect. In additional comments, more than half mentioned their surname or given name as important, while five mentioned their race, and three mentioned their religion.

\section{A child's name and the future}

In the survey, the respondents were also asked to give their views as to whether they thought a name was an important factor that would determine a child's future. All respondents replied positively to this question as shown by the sampling of responses.

From Malay respondents:

I. The name is linked to the Quran, that is, my religion.

2. Names in Islam should have meanings.

3. Names define children.

4. A child is believed to be as how the name suggests.

5. In Islam a name is like a prayer for the child. 
6. With Arabic names, when we call our children they respond thereby confirming what we call them.

From Chinese respondents:

I. Having a good name is important.

2. There might be poking fun and hurting feelings if the name is not chosen with care.

3. A name determines health and wealth.

4. Parents want the best name for their child.

5. Children know their parent's expectations and live up to them.

6. One's character is based on one's name.

The reasons given by the Chinese respondents show how the choice of name is guided by economic factors, that is, the desire for upward economic mobility. Common Chinese names relate to such concepts as health, longevity, wealth, and prosperity; for example, Fook indicates 'longevity,' Fatt 'prosperity,' and Ming 'intelligence.' The focus on surnames, as described earlier, also points to the importance of ancestry.

Among the Malays, the choice of names is strongly linked to religion. Further there is focus on the nuclear rather than extended family, that is the child carries the father's name but there is no surname. While Chinese names do not indicate gender and in fact some Chinese names are unisex, for example, Ming can be male or female, Malay names indicate the gender of the child through the use of bin and binti.

One interesting and important finding in this study is the fact that two-thirds of the respondents indicated that they did not mind if people mispronounced their names. This appears to be in direct contrast with findings that indicate that mispronunciation of a name is resented because it amounts to distortion of their identity in that a misrepresentation of one's name amounts to a misrepresentation of the person (Deluzain, I996).

\section{Ethnic identity}

A national survey reported in the Star newspaper found that racial integration is still not yet a reality in Malaysia. The survey found that the majority of respondents still identified themselves according to their race and religion. When asked what they considered themselves to be first the following results were obtained:

$$
\begin{array}{lll}
\text { Malays } & \text { Chinese } & \text { Indians } \\
6 \mathrm{I} \% \text { - religion } & 47 \% \text { - ethnicity } & 75 \% \text { - Malaysians } \\
28 \% \text { - Malaysian } & 44 \% \text { - Malaysian } & \mathrm{I} 4 \% \text { - ethnicity } \\
5 \% \text { - ethnicity } & 5 \% \text { - religion } & 5 \% \text { - religion } \\
& & \text { (Star, 2I July 2006) }
\end{array}
$$

The survey results show that, while the Malays identify with their faith and the Chinese identify with their ethnic background, it is only the Indians who identify themselves as a race who is truly Malaysian.

The findings of the newspaper survey tie in with the findings of the researcher's survey, which showed that the respondents identified with their language first of all, followed by their culture and finally their dialect. In other words ethnic identity is as important as one's language and culture and is tied to one's ethnicity. The placement 
of dialect in the third place reinforces the importance of ethnic identity. This can be seen in an example where one is first of all Chinese and at the micro level belongs to the Hakka clan, which speaks Hakka. Likewise among the Malays in Malaysia one can then look at the dialect groups, for example, the Kelantanese speak the Kelantan dialect, and so forth.

\section{Empowerment and the name system}

Malaysia is a patriarchal society and the name system is one that is gender driven. Hence while the male gender is empowered via the patriarchal system, the female gender is disempowered via the very same system. Among the Chinese this is seen in the fact that girls do not carry the same generation name as the boys and when they marry they no longer carry the family surname. The boys then are the ones who not only ensure the continuance of the family lineage and surname, they also ensure that the land and property is kept within the family.

Among the Malays, one notes that the lack of a surname in the name system does not in any way empower the female gender. On the other hand, their religion which is the most important factor in determining their identity, further disempowers the female gender. This is by virtue of the fact that the Muslim religion allows Muslim men to marry four wives at any one time. Hence this puts great pressure on women to obey their husband, failing which the husband may choose to marry another.

In conclusion, one finds that the Chinese female is disempowered by the ancestry system, once married she is literally cut off from her ancestral roots. The Malay woman is disempowered by her religion as is the Indian woman. Among the Indians, men are to be treated as almost god-like beings. Hence the wife is expected to serve and obey her husband at all times. When her husband dies, she is not free to do as she pleases, rather she will now be under the care of her eldest son.

\section{Globalization and the shift in power}

Globalization has brought about the creation of a borderless world. This has impacted the politics and economics of countries around the world. Among linguists the impact of globalization on the lingua franca has been a subject of study and analysis. Malaysia has also been impacted by globalization and this is seen in the trend towards using the English Language to teach content subjects in schools. This move was made to ensure that Malaysia stays economically viable in the global world. A global world perhaps then translates into a world that sees the survival of the fittest. Hence the existing patriarchal system that favors male progeny may soon have to give way. This system of male progeny may be seen as a liability as it does not ensure the survival of the best. Global competition may bring about a new system to replace the existing patriarchal system. What may emerge will be a system that nurtures the best and only the ones who are relevant in the global game. This may in turn give way to a new global naming system.

\section{Conclusion}

Names in multilingual-multicultural Malaysia prove to be an interesting study. While the factors that determine the identity of an individual in Malaysia are diverse, the 
three most important are language, culture, and dialect. The patriarchal system plays an important role in the name system of the country and this is especially true for the Chinese community. The name system of the Malay community is very much guided by the Muslim religion and the Quran. Likewise the Indian community is guided in the naming system by its religion. In general, religion and economic factors play an important role in the Malaysian name system. Nevertheless, the borderless global world which has seen the proliferation of fusion foods and fusion cultures has also impacted the name system. Reid (2006) uses the term hybrid names to describe names that incorporate an English name with a Chinese, Indian, or Malay name, for example:

$$
\begin{aligned}
& \text { John Toh (Chinese) } \\
& \text { Anthony Samy (Indian) } \\
& \text { Nadia Binti Mahmud (Malay) }
\end{aligned}
$$

Such a name system may reflect the movement away from ethnic and nation identity to one of global identity. This may encourage movement away from such factors as religion and patriarchy and towards such factors as economic considerations in the name system.

\section{Bibliography}

Deluzain, Edward H., I996. Names and Personal Identity, http://www/behindthename.com

Louie, Emma Woo, 2005. 'Remarkable Similarities Between Traditional Chinese and Anglo-Saxon England's Naming Customs,' Names, 54: 21 I-20.

Reid, Anthony J., 2006. 'Southeast Asian Names: Why it makes a Difference?' Paper presented at a seminar at Asia-Europe Institute, University of Malaya, Malaysia, 4 December 2006.

'Mother of missing baby not eating and sleeping right,' Star, 23 June 2005, Nation section, Malaysian edition.

'China recognizes Confucius women kin for first time,' Star, 27 September 2006, World updates, Malaysian edition.

'The Malaysian not there yet,' Star, 2I July 2006, Nation section, Malaysian edition.

\section{Note on Contributor}

Karen Kow Yip Cheng is an Associate Professor in the University of Malaya. Her first degree is in English Literature, and she holds a Master's Degree in Linguistics. Her $\mathrm{PhD}$ is in the area of child language. She has published widely in the areas of child language, applied linguistics, gender, children's literature and bilingualism. Her other areas of research include second language acquisition, bilingualism and recently names with a focus on relationships between ethnicity and names.

Correspondence to: Karen Kow Yip Cheng, University of Malaya, 50603 Kuala Lumpur, Malaysia. Email: kowyc@um.edu.my 